Synthesis, part of a Special Feature on The Conservation and Restoration of Old Growth in Frequent-fire Forests of the American West

\title{
Living among Frequent-fire Forests: Human History and Cultural Perspectives
}

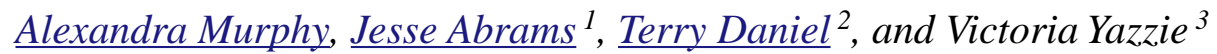

\begin{abstract}
Ecological and social factors shaped old-growth forests of the western United States before Euro-American settlement, and will, in large part, determine their future. In this article, we focus on the social factors that affected the forest's ecological structure and function, review the changing cultural influences through law and policy of public land management and use, and discuss the changing public perceptions of fire use. We also provide an overview of the current debates about the conservation of oldgrowth forests, and the current congressional protection and management of old-growth forests in public land management and use.
\end{abstract}

Key Words: Euro-American land-use practices; fire suppression; indigenous peoples'forest management; land ethic; post-WWII environmental legislation; preservationist philosophy; utilitarian philosophy

\section{INTRODUCTION}

The current condition of old growth in frequent-fire forests-the ponderosa pine (Pinus ponderosa)covered Black Hills region; the pine (Pinus spp.) and mixed-conifer forests of the Southwest, Rocky Mountains, and interior Northwest; and the sequoia (Sequoiadendron giganteum) and mixed-conifer forests of the Sierra Nevada-stems from a host of ecological and social forces that shaped these forests. This article focuses on the latter: the social forces that have affected the forests' ecological structure and function and will, in large part, determine their future. These social forces have wrought changes that range from localized effects around major population centers to landscape-level alterations in composition and structure (Delcourt and Delcourt 1997, Freiderici 2003, Anderson 2005). Although people have inhabited frequentfire forests for millennia, human activities during the last two centuries have fractured the ecological and sociocultural processes that perpetuated oldgrowth forests in low- to moderate-severity, frequent-fire regimes.

\section{MILLENNIA OF COEXISTENCE: NATIVE AMERICAN INHABITANTS AND THE ENVIRONMENT}

All human cultures alter their environments to some extent, both intentionally and unintentionally. A culture's stability depends in large part on how successfully these alterations maintain the environment's ability to sustain itself. Although the landscape initially shapes the choices available to the humans that inhabit it, the people, in turn, reshape that landscape in responding to those choices (Crumley 1994, Yazzie 2006). In terms of the relationship between people and North America, Stephen Pyne writes that: "The modification of the American continent by fire at the hands of Asian immigrants [now called American Indians, Native Americans, or First Nations/People] was the result of repeated, controlled, surface burns on a cycle of one to three years, broken by occasional holocausts from escape fires and periodic conflagrations during times of drought" (Pyne 1982, pp. 79-80). 
For more than 10000 years, Native Americans have lived in the frequent-fire, old-growth forests of the interior West. In those old-growth forests, they have hunted, cultivated food, fished, camped, gathered berries and nuts, collected firewood, found spiritual sustenance, and altered the landscape by purposefully lighting fires. Indigenous fire management shaped the structure and composition of frequent-fire forests at the landscape scale, through carefully timed burning at specific locations. For example, Lewis and Clark credited seven of ten fires they encountered in the Lolo Pass region of western Montana to indigenous burning (Gruell 1985a). In the Sierra Nevada region of California, indigenous burning enhanced the quantity and improved the qualities of plant species used for food, medicine, ceremonies, and baskets (Anderson 2005).

The Confederated Salish and Kootenai Tribes of the Flathead Indian Reservation in western Montana view fire from a different perspective than EuroAmericans. In their tradition, fire is a gift from the Creator, brought to them by the animals. This gift has been used for thousands of years in frequentfire ecosystems - from dry ponderosa pine forests to moist, mixed-conifer forests (White 2006). As a result of frequent use of fire by Native Americans, the mixed-conifer forests of the Cordillera (the mountainous region of the western United States) were once composed of lightly stocked stands of shade-tolerant species, fire-tolerant tree species, and understory vegetation of grasses, forbs, and shrubs (Arno and Fielder 2005, McKenzie et al. 2006). Native peoples used fire to drive game and open the forest to increase visibility and improve forage (Kay 1995). Fire use encouraged the growth of plant species essential for ceremonies and medicinal use (Kimmerer 2000, Kimmerer and Lake 2001, Turner et al. 2003, Anderson 2005). Indigenous fire use remains a tool to maintain cultural integrity and cultural resources within Native American communities - a tool that modifies, maintains, and restores the structure and composition of frequent-fire forests to meet cultural needs and subsistence use (Arno 1980, Kay 1995, Kimmerer and Lake 2001, Anderson 2005). From the indigenous perspective, the use of fire is a mutually beneficial relationship between the landscape and the people. This relationship reveals the history and culture of the people who live in it (Yazzie 2006), and the place-based environmental values they have developed (Berkes et al. 2000, Moller et al. 2004, Yazzie 2006).
In ecological terms, low-severity fires in southwestern ponderosa pine ecosystems, whether ignited by lightning or Native Americans, historically occurred at intervals ranging from 2-35 years, whereas high-severity fires were rare or nonexistent (Weaver 1967, Cooper 1960, Covington and Moore 1994b). By maintaining an open stand structure, low-severity fires limited the scope and severity of insect outbreaks and kept dwarf mistletoe (Arceuthobium spp.) in check (Covington 2003, Alcoze 2006). High-severity fires did, however, occur periodically in dry forests in other parts of the West (Shinneman and Baker 1997, Veblen et al. 2000, Bonnicksen 2000). Fires burned less frequently within many mixed-conifer forests in the Inland West, with mean fire return intervals of 5-25 years in the warm, dry ecosystems and 3545 years in the cool, moist ecosystems (Arno 1980, Fischer and Bradley 1987).

\section{CHANGING INHABITANTS, CHANGING ECOLOGY}

During the $16^{\text {th }}$ century, Spanish explorers made their first forays into the frequent-fire forests of the interior West. Two hundred years before Lewis and Clark embarked on their Journey of Discovery, Juan de Oñate and a band of Spanish settlers marched north through the dry forests of New Mexico, bringing with them thousands of head of livestock (Scurlock and Finch 1997). Since that time, EuroAmerican influences have dramatically altered frequent-fire old-growth forests through interactions that roughly divide into four periods: 1) a period before the mid-19 ${ }^{\text {th }}$ century, characterized by a relatively low Euro-American population; 2) a period of rapid Euro-American expansion into the West from 1850-1900, characterized by unregulated exploitation of old-growth resources; 3 ) a period from 1900 through the 1960s, characterized by increased governmental control and regulation of Western forests, guided by a philosophy of use; and 4) a period from the $1960 \mathrm{~s}$ until the present, characterized by increasingly successful challenges to the use philosophy by an environmentally concerned public.

\section{Early Euro-American Settlement}

When Euro-Americans began settling western frequent-fire forest regions, they often encountered open forests of large, old trees with a dense ground 
cover of grasses and forbs (Oliver et al. 1994, Robbins and Wolf 1994, Langston 1995, Beesley 1996). Although there is no definitive information on the proportion of presettlement forests in oldgrowth condition, the accounts of early explorers suggest an abundance of large, mature trees, as in this passage from C. Hart Merriam's report on an exploration of northern Arizona: "It is a noteworthy forest, not alone on account of the size and beauty of the single species of tree of which it is composed (Pinus ponderosa), but also because of its openness, freedom from undergrowth, and its grassy carpet.... The pine forest is thoroughly mature, nearly all the trees being of large size, and rarely crowded..." (Merriam 1890, p. 119).

Above the arid grassland plains and below the dense thickets of spruce-fir (Picea spp.-Abies spp.) and lodgepole pine (Pinus contorta subsp. murrayana) at higher elevations, frequent-fire forests provided easy travel-even for horse-drawn wagons-and attractive places for livestock grazing and settlement (Langston 1995, Bonnicksen 2000). Less attractive were the frequent understory fires and attendant haze of smoke that interfered with travel and seemed wasteful to some early settlers (Robbins and Wolf 1994, Langston 1995).

Before the mid-1800s, few Euro-Americans inhabited the West's frequent-fire forests. Those that did were largely fur trappers, traders, missionaries, and, in places, communities of Spanish descent. Although some limited logging for building and firewood purposes took place, the overall effect of timber harvest on old-growth forests was minimal (Scurlock and Finch 1997). Grazing by domestic sheep, cattle, goats, and horses may have had a more significant effect on forests near early Euro-American settlements (Scurlock and Finch 1997) and in the vicinity of indigenous communities that acquired European livestock (Savage and Swetnam 1990, Scurlock and Finch 1997, Hessburg and Agee 2003). Despite these localized grazing effects, low-intensity ground fires still regularly sculpted frequent-fire forests throughout much of their range.

It is difficult to estimate the proportion of frequentfire forest that existed in an old-growth condition before widespread Euro-American settlement. Not only are published estimates rare, but differences in old-growth definitions can affect how old-growth acreage is calculated. Taking a very fine-scale approach, Bonnicksen (2000) notes that "old pioneer forest" in the ponderosa pine type probably constituted less than $40 \%$ of pre-European settlement conditions, more typically ranging from $17 \%$ to $25 \%$, with grassy openings and younger forests comprising the remainder. Beardsley et al. (1999) report that around $45 \%$ of current Sierra Nevada forest in "reserved" status (wilderness areas, parks, and private reserves) was in old-growth condition in 1993, and they suggest this figure as a rough estimate of the proportion of old growth that could exist under a natural disturbance regime. However, this figure includes higher-elevation forest where fire only infrequently occurs. Between $10 \%$ and $26 \%$ of mixed-conifer sites in the Sacramento Mountains of New Mexico may have been old-growth before 1898, based on early inventory data (Regan 1997). Langston (1995) references a 1912 report in which $85 \%$ of ponderosa pine-dominated acres on the Wallowa and Minam National Forests in northeastern Oregon were found in an old-growth condition; vast stretches of frequent-fire forests in mostly old-growth condition were found in other nearby forests. These disparate figures do not clarify an overall estimation of preEuro-American settlement forest conditions, but they do suggest that old growth constituted a significant proportion of forests in the western United States.

\section{Westward Expansion}

Euro-American immigration into the West's frequent-fire forests increased dramatically in the mid- to late $19^{\text {th }}$ century. Several factors prompted this: discoveries of gold and other valuable minerals, rapidly expanding railway service to the West, and government incentives to settlers (Langston 1995, Beesley 1996, United States Department of Agriculture (USDA) Forest Service 1996). When settlers encountered the West's expansive, seemingly inexhaustible old-growth forests, they quickly set about exploiting them (Beesley 1996, Scurlock and Finch 1997, Hessburg and Agee 2003). Industrial-scale timber harvest soon provided structural lumber, fuel wood, railroad ties, and mining timbers to local and regional markets (Robbins and Wolf 1994, Geores 1996).

As rail connectivity increased, settlers increasingly shipped lumber from the old-growth forests out of the region to destinations as distant as New York City (Friederici 2003). Rail expansion also ushered in the era of "railroad logging" in which loggers 
high-graded the old-growth forests of the interior West, felling the largest, straightest trees. Often only the valuable bole was loaded on the train, and the rest of the slash and debris left on site. Sparks from skidding and loading machinery and passing trains often ignited this debris, causing uncharacteristic, high-intensity fires in cutover areas (Williams 1908, Robbins and Wolf 1994, Langston 1995). Early logging practices were focused on the removal of the highest-value timber with little or no thought given to reforestation. Once land had been cut, timber companies often abandoned it and moved on (Wilkinson 1992, Langston 1995).

Early grazing practices also acted to maximize short-term economic gain, with little understanding of long-term consequences. Cattle and sheep severely overgrazed openings and understories in old-growth forests, eliminating the grasses that fueled the spread of surface fires (Robbins and Wolf 1994, Beesley 1996, Covington 2003). The relationship between overgrazing and fire cessation is illustrated by the localized disappearance of frequent fires coincident with overgrazing early in the $19^{\text {th }}$ century in northeastern Arizona (Savage and Swetnam 1990). Tree-ring analyses in Arizona ponderosa pine forests have shown that regularly occurring, low-severity fires virtually disappeared from the landscape by the late 1800s (Dieterich 1980).

The effects of Euro-American land-use practices and policies toward Native Americans began to transform frequent-fire, old-growth forests during the coming decades. High-grading changed the complex forest structure that was typical of oldgrowth frequent-fire forests (Covington 2003) and altered fire regimes in logged-over areas, encouraging hot burns that consumed slash and remaining trees (Robbins and Wolf 1994, Beesley 1996, Scurlock and Finch 1997). Overgrazing reduced the fine, flammable materials of the understory, thereby removing a key component of the frequent, low-severity fire regime that had characterized these forests for thousands of years (Cooper 1960, Savage and Swetnam 1990). As Euro-American settlement spread throughout the West, indigenous tribes that had historically encouraged low-severity fires were dislocated, under attack, or confined to reservations by settlers and the United States military (Hessburg and Agee 2003).

Heavy grazing and timber cutting produced two common results: 1 ) increases in shade-tolerant, fire- intolerant tree species and 2) overall increases in tree densities (Hessburg and Agee 2003). Some harvested ponderosa pine forests in the dry forests of the Northwest became lodgepole pine and true fir forests, often at high densities. This transformation eventually led to high tree mortality, susceptibility to insect and disease infestations, and a shift to a stand-replacing fire regime (Langston 1995). In moist ponderosa pine forest sites, true fir and Douglas-fir (Pseudotsuga menziesii) began reproducing vigorously in the understory, creating fuel ladders that could carry fire into the canopy (Weaver 1943, Hessburg and Agee 2003). In the Southwest, grazing, logging, and fire exclusion combined with climatic conditions to result in an eruption of ponderosa pine seedlings, the legacy of which persists to this day (Cooper 1960, Covington 2003).

\section{GOVERNMENT REGULATION AND THE UTILITARIAN PHILOSOPHY}

By the time Euro-American settlers began to exploit the West's resources in earnest, much of the forest land in the eastern half of the United States had already been cut over or converted to agriculture (Williams 1989). As in the West, early cutting practices in the East - particularly in the Lake States -tended to resemble "timber mining," with little or no thought given to regeneration of future forests or the condition of the post-logging landscape (Hirt 1994, Williams 1989). When settlers and lumbermen reached the interior West and West Coast, the country was faced with the geographic limits of its forest resources. It became clear that, at current rates of cutting and under common harvest practices, the nation would soon exhaust its supply of standing timber. Concerned about wasteful logging and grazing practices, and fearful of an impending nationwide "timber famine," Congress authorized the creation of forest reserves in 1891 (Clary 1986). In 1897, Congress passed the Organic Act, giving the federal government authority to regulate "occupancy and use" of the reserves and to restrict timber harvest to "dead, matured, or large growth of trees." It also called for the forest reserves to be protected against "destruction by fire."

The purposes for these forest reserves remained unclear until 1905, when Division of Forestry Chief, Gifford Pinchot, had them transferred to the Department of Agriculture and branded them with his Progressive-era vision of conservation. President Theodore Roosevelt, under Pinchot's 
guidance, greatly increased federal control of western forests by designating more than 100 million acres of western land as "national forests." Pinchot changed the name from "forest reserves" to indicate that the forests would not be reserved from management (Wilkinson 1992). Most of the West's frequent-fire forests would eventually become part of the National Forest System.

In the utilitarian land management philosophy of Pinchot and Forest Service chiefs that followed, forests were storehouses of raw materials to be converted into goods for human use (Clary 1986, Wilkinson 1992). From this perspective, old growth was an inefficient storehouse because the net growth in older forests tends to be low or even negative, with annual additions of wood volume offset by mortality and decay. For this reason, old-growth forests were referred to as "overripe" or "overmature," even seen as "parasitic" for taking up space that could otherwise be occupied by more productive, younger forests (Langston 1995). Old growth lacked intrinsic value to early forest managers, who believed older forests would best serve human purposes if converted to well-managed second growth. Pinchot's vision of forest management resulted in ongoing timber, grazing, and fire policies that dramatically reduced the quantity and quality of old growth in frequent-fire forests within the National Forest System (Langston 1995, Covington 2003).

\section{Timber Policies}

Pinchot's utilitarian philosophy called for eliminating waste in forest management. Waste primarily existed in two forms: 1) destructive logging practices that left forests in poor condition and 2) unharvested old-growth forests (Wilkinson and Anderson 1987, Hirt 1994, Langston 1995). Guided by the principles of sustained yield, Pinchot made the conversion of economically stagnant, oldgrowth forests to vigorous second-growth a top priority (Wilkinson and Anderson 1987). Indeed, early federal foresters believed that harvesting existing old growth and setting the stage for productive younger forests was a duty of national importance because it was the only way to prevent an impending timber famine (Langston 1995). During the first few decades of the $20^{\text {th }}$ century, national forest timber sales on dry western forests combined with those on private lands and Bureau of Indian Affairs-administered reservation lands to supply logs to new mills (Baker et al. 1988, Scurlock and Finch 1997). Ponderosa pine throughout the West, in addition to Jeffrey pine (Pinus jeffreyi) and sugar pine (Pinus lambertiana) in the Sierra Nevada, were favored species, constituting more than $99 \%$ of harvested timber in some places (Robbins and Wolf 1994, Beesley 1996).

\section{Fire Policies}

The Forest Service's policy of suppressing all fires began under Pinchot's leadership, but was adopted only after several years of intense debate within state and federal forestry circles (Pyne 1982). Some early western scientists, including John Wesley Powell, noted the beneficial effects of low-severity fire (Pyne 2001, Stephens and Ruth 2005, Alcoze 2006). Powell believed that, through their burning practices, Native Americans in the Southwest prevented catastrophic fires and maintained landscape productivity sufficient to sustain their populations (Alcoze 2006). Opponents derided indigenous fire management as "Paiute forestry," and believed that low-severity fire would damage mature timber and decrease timber production (Pyne 1982, Beesley 1996, Alcoze 2006). After the fires of 1910, which burned three million acres in the northern Rockies and killed 85 people - most of them firefighters-the Forest Service's total suppression policy gained strong support (Pyne 1982 , 2001). In 1935, the agency went so far as to adopt a policy that all fire starts were to be extinguished by 10 a.m. the following morning (Pyne 1982). By the early decades of the $20^{\text {th }}$ century, the creeping ground fires that had sculpted and maintained interior old-growth forests for millennia would be almost universally absent from the landscape. Needles, cones, branches, brushy undergrowth, and slash from timber harvests accumulated on the forest floor in the absence of fire, and large quantities of young trees filled the forest understory, ready to fuel high-severity fires.

\section{Grazing Policies}

By the time the first forest reserves were established in the late $1800 \mathrm{~s}$, much of the grassy and herbaceous understory of frequent-fire forests in the West had already been intensively grazed (Beesley 1996, Scurlock and Finch 1997). Euro-American settlers saw the western range as a free public resource, which made the regulation of grazing a difficult task. 
Early grazing regulation helped establish rights to particular allotments, improve management practices, and institute nominal grazing fees, but did not significantly reduce herd sizes (Beesley 1996). In fact, the overall number of livestock on public and private lands increased during the early decades of the $20^{\text {th }}$ century, although herd numbers were reduced in some locales (Beesley 1996, Wilkinson 1992).

It is important to note that the history of frequentfire old-growth forest during this period is not simply a story of national forest lands. Millions of acres of old growth were once found on privately owned land and on Native American reservations. Since Euro-American settlement, old-growth forests on private lands have largely been liquidated, generally before World War II (Hirt 1994). Oldgrowth forests can still be found today on isolated parcels of private land, but these are rare exceptions (Beardsley et al. 1999).

\section{EARLY VOICES FOR PRESERVATION}

One of the earliest and best-known voices calling for the preservation of western forests was John Muir. His preservationist philosophy was both biocentric - in the sense that it valued all natural entities for their own sake rather than their utility to mankind-and deeply religious (Nash 1967). Muir saw the newly created western forest reserves not as storehouses for human use, but as "terrestrial manifestations of God" imbued with inherent value. Speaking of the forests of the Sierra Nevada, Muir protested: "The gardens of the Sierra also, and the noble forests in both the reserved and unreserved portions, are sadly hacked and trampled, notwithstanding the ruggedness of the topography.... In the noblest forests of the world, the ground, once divinely beautiful, is desolate and repulsive, like a face ravaged by disease" (Muir 1898, p. 17).

Although Muir was a minor celebrity in his time, and his fledgling Sierra Club had a sizeable local following, societal demands to preserve, rather than liquidate, old-growth forests were too weak in the early $20^{\text {th }}$ century to significantly alter management direction for most western public land (Nash 1967). Some of the more spectacular landscapes were transferred out of Forest Service jurisdiction to become national parks, but the primary forces preserving old-growth in the interior West were low timber prices, the inaccessibility of the terrain, and pressure by timber barons to keep federal wood off the market (Clary 1986, Wilkinson 1992, Beesley 1996). As long as there was an abundant supply of large trees on private land, federal timber was seen as competition, threatening to drive prices lower (Wilkinson 1992, Nelson 1995).

Nonetheless, Muir's vision of a preservationist approach to public lands both inspired and articulated a growing societal demand for wild, undeveloped nature. His philosophy is often contrasted with the utilitarian approach of his onetime friend Pinchot, and battles between preservation and utilization would come to define much of the landscape of federal forest management later in the $20^{\text {th }}$ century.

The first credible call for a change in the utilitarian management philosophy from within the ranks of the Forest Service came from restoration pioneer, Aldo Leopold. Leopold began his career as a loyal agent of the utilitarian-focused Forest Service, taking part in predator eradication and arguing against "Piute [sic] forestry" (Leopold 1920). However, his time spent observing the changes wrought by decades of manipulating the forest to meet mankind's material needs caused a sea change in his thinking. Rather than seeing the forest as a collection of independent resources of variable value to humans, he saw it as a complex, interconnected system, wherein manipulating one part (e.g., predators or fire) would have unintended second-order effects that would reverberate throughout the system (Leopold 1939, 1949, Callicott 2000).

Leopold's influence on management of old growth in frequent-fire forests was significant for several reasons. His early calls for the preservation of wilderness areas prompted the administrative designation of the Gila Wilderness in 1924 and, eventually, the Wilderness Act of 1964. Perhaps just as significantly, Leopold's ecological vision articulated a role for humans in the ecosystem that was neither commodity driven nor purely aesthetic or romantic. Some authors have compared Leopold's land ethic to the Native American land management philosophy, both in its extension of ethical considerations to the non-human world and in its inclusion of humans as an integral part of a complex, dynamic ecosystem (e.g., Anderson and Moratto 1996). This land ethic-whether called "Leopoldian" or "Native American"-forms an important starting point for the management of oldgrowth forests in fire-prone landscapes. 


\section{POST-WORLD WAR II AMERICA}

World War II served as a turning point for federal forest management because of the massive demand for wood to support both the war effort and the postwar housing boom (Hirt 1994, Nelson 1995), and because increased mechanization following the war boosted the efficiency of timber cutting and hauling (Hessburg and Agee 2003). Old-growth and other merchantable forests had largely been removed from private lands by this time, and the nation turned to the West's federal forests with their as yet untapped bounty of large trees.

However, America's post-war prosperity also meant that more people had time to drive, vacation, and recreate - often in and around national forests, where they came into contact with increasingly intensive, industrial-style timber management practices (Clary 1986, Baker et al. 1988, Wilkinson 1992, Hirt 1994). In 1960, Congress legitimized non-commodity uses in national forests with the passage of the Multiple Use-Sustained Yield Act, which listed outdoor recreation and conservation of wildlife habitat as purposes of national forests. Although the "multiple use" side of the legislation recognized non-commodity forest values, the "sustained yield" side made it clear that old-growth forests would continue to be cut to make way for faster-growing secondary forests (Clary 1986). The post-war emphasis on multiple use and sustained yield led to ever more complex and overly optimistic schemes to increase timber outputs from federal lands while trying to address the growing demand for non-timber uses of national forests (Hirt 1994, Clary 1986). This dynamic, rather than a concern about a future timber famine, would come to define federal forest management in the decades following World War II.

By the early 1960s, more and more Americans began to express concern for the environmental effects of industrialization: declining water and air quality, degraded wild places, and loss of plant and animal species. Outdoor recreation was booming, and with it, the membership rolls of environmental organizations, such as the Sierra Club and The Wilderness Society (Baker et al. 1988, Hirt 1994). At the same time, there was a growing recognition in the scientific community of the ecologically beneficial role of fire. The 1963 "Leopold Report" on wildlife management in national parks posited that fire was a natural process and should be integrated into park management (Leopold et al. 1963).
In 1964, after years of failed attempts, Congress passed the Wilderness Act as a means of preserving wild places on public land. According to the act, wilderness was to be "an area where the earth and its community of life are untrammeled by man, where man himself is a visitor who does not remain." Upon signing the act into law, President Lyndon Johnson remarked on the importance of leaving future generations "a glimpse of the world as it was in the beginning, not just after we got through with it." The American public increasingly saw protection of old-growth forests and other natural areas as a process of excluding or minimizing human influence on natural systems (Nash 1967).

Although the American environmental movement continued to gain political strength and popular support, the U.S. Forest Service held fast to its emphasis on commodity production and fire suppression, and to its faith that increasingly intensive forest management practices would result in greater benefits for all (Clary 1986, Hirt 1994). Lawsuits by environmental and sportsmen's groups in the 1970s successfully challenged forest management practices, including clearcutting, on national forests, culminating in the 1975 "Monongahela" decision that temporarily shut down all clearcut logging on national forests (Wilkinson 1992). Congress responded with the National Forest Management Act of 1976, which increased public involvement in, and scrutiny of, national forest plans and practices. Congress also responded to public demands for environmental protection by designating wilderness areas throughout the coming decades. Although these areas were largely concentrated in scenic, higher elevation locations, many wilderness areas included at least some frequent-fire forest acreage (Beardsley et al. 1999, Arno et al. 2000, Kipfmueller and Swetnam 2000).

Despite the growing number of designated wilderness areas, the conversion of old growth to young stands continued at a record pace through the 1970 s and 1980s (Hirt 1994). Even those frequentfire old-growth forests that remained unharvested were vastly changed in terms of structure and biological integrity. As early as the 1940s, some foresters became concerned with changes occurring in western frequent-fire forests, and they linked these changes to decades of fire exclusion (Weaver 1943). By the mid-20 ${ }^{\text {th }}$ century, forests that historically experienced only creeping ground fires were being consumed by high-severity crown fires 
(Savage and Mast 2005). In 1960, Charles Cooper published a seminal investigation of changes in ponderosa pine stand structure caused by fire exclusion, contrasting current overstocked, crownfire-prone conditions with forest conditions before European settlement (Cooper 1960).

By the late 1980s, public attention focused squarely on old-growth forests, but it was the damp, oldgrowth forests of the Pacific Northwest that held the stage, not the dry, frequent-fire forests of the interior West (Yaffee 1994, Wilkinson 1992). On one side of the debate were loggers, the timber industry, resource-dependent rural communities, and their allies arguing that old-growth forests should be cleared to provide jobs and set the stage for future, fast-growing forests. On the other side were environmentalists, wildlife advocates, and others who wanted the forests left alone and protected from human influences.

Public discourse at the time characterized oldgrowth forests as "ancient," "virgin," and "primeval" (Norse 1990), whereas individual stands were described as "cathedral-like" (Carey 2003). Old-growth forests perfectly characterized an ideal of untouched nature, and opponents of old-growth logging used this to their political advantage, often employing metaphors of chastity and religious sanctity to describe unlogged forests (Davis 1995). Conversely, logged forests were often described as having been violated or defiled (Davis 1995). The old-growth showdown in the Pacific Northwest was largely settled with creation of the Northwest Forest Plan (USDA and United States Department of the Interior (USDI) 1994), which shifted management emphasis from timber production to wildlife and watershed protection.

Not long after the old-growth dispute in the Pacific Northwest reached its apex, similar legal and political battles emerged in drier, fire-prone forests of the interior Northwest, Southwest, and Sierra Nevada. The issues were strikingly similar, with old-growth forests at the center of divisive conflicts over endangered species, road-building, timber harvests, and other issues (Nie 1998, Erman 1999, Quigley et al. 1999). These conflicts were-and continue to be-complex and highly politicized, with implications for the future of old-growth forests. In general, all three of these regions experienced reductions in timber harvests and consequent loss of workforce and milling capacity. The harvests that did continue tended to focus on smaller-diameter material and salvage of fire- or insect-killed trees. Management direction, guided by ecosystem management principles (Grumbine 1994), signaled an end to the emphasis on oldgrowth conversion, and subsequent policies guided management toward restoring more natural forest structures and fire regimes.

During this time, the American public increasingly voiced concern for the non-commodity values of frequent-fire old growth-recreational, aesthetic, spiritual, and ecological. At the same time, surveys revealed an increased understanding of the role of fire in maintaining the structure and ecological functions of frequent-fire old growth. As early as 1981, two-thirds of survey respondents in southern Arizona acknowledged the beneficial effects of fire on forests (Cortner et al. 1984). In surveys in 2000, 2002, and 2003, a majority of people living in the Southwest supported the use of prescribed fire in forest management, and believed that prescribed fire reduces wildfire risk and severity (Abrams and Lowe 2005).

Throughout the West, conflicts over the management of frequent-fire old-growth forests changed the legal, political, and economic frameworks for forest management, even if these changes were never explicitly delineated in Congressional policy (see article by Vosick et al. in this issue). The curtailment of old-growth logging was a necessary, but insufficient, step in the conservation of frequent-fire old-growth. Although old-growth forests were largely protected from the chainsaw, even greater threats continued to loomcompetitive stress from the smaller trees that had grown up in the absence of fire, insect infestations made more severe by both competitive stress and drought, and the growing risk of stand-replacing fire in these unnaturally crowded forests.

A series of fierce political battles about the fate of old-growth forests waged through the 1990s. The decade also saw a rash of expensive, destructive fire seasons throughout the West, including the 1994 fire season, which resulted in 34 fire-related fatalities. The 1995 Federal Wildland Fire Management Policy was the first national fire policy document to recognize the role of fire as an ecologically important natural process, even as it indicated methods to reduce the negative effects of high-severity wildfire. The National Fire Plan, first developed in 2000 after another particularly costly fire season, posited that "the removal of large, 
merchantable trees from forests does not reduce fire risk and may, in fact, increase such risk."

As federal forest managers shifted their focus from wood fiber production to restoration and fuel reduction, public disputes about tree removal remained a constant part of the sociopolitical landscape. The removal of large trees during restoration operations was a practice that engendered a particularly high level of controversy (Friederici 2003). Old-growth forests received their first explicit Congressional protection as part of the Healthy Forests Restoration Act of 2003. Section 102(e) of that legislation requires forest managers carrying out authorized hazardous fuels reduction activities to "fully maintain, or contribute to the restoration of, the structure and composition of oldgrowth stands according to the pre-fire suppression old-growth conditions characteristic of the forest type...and retaining the large trees contributing to old-growth structure." Despite this safeguard, restoration projects continue to be contentious and as a result, much work to date has focused on reducing fuels in the wildland-urban interface. Forests in the backcountry, including degraded remnant stands of old growth, continue to exist in a state of imminent collapse, threatened by unnaturally high populations of young trees and attendant risks of crown fire and insect attack (Mast et al. 1999).

\section{THE CURRENT MANAGEMENT CONUNDRUM}

Two centuries of overgrazing, high-grade harvesting, and fire exclusion have made former frequent-fire forested ecosystems prone to standreplacing fire, devoid of a rich and diverse understory, and too dense to produce valuable timber. Much of this degradation can be attributed to human (especially Euro-American) views of frequent-fire forests as either limitless frontiers or as engineered industrial landscapes. At the same time, a purely preservationist strategy of excluding human influences altogether appears to be an untenable strategy for old-growth protection in frequent-fire forests (Agee 2002). The conservation and restoration of frequent-fire old-growth forests may depend on fostering a relationship between humans and forests that avoids the pitfalls of both utilitarianism and preservationism.
There are, however, no easy solutions for attaining and sustaining public support for the management interventions needed to restore an old-growth condition in frequent-fire forests. The increased risks of injury and property damage from escaped fires and negative reactions to smoke and scorched landscapes can be substantial obstacles to ecologically motivated fire management near rapidly expanding developments. Even though residents in the wildland-urban interface have been exposed to extensive fire-safety programs in recent years, they continue to perceive the situation in terms of a trade-off between uncertain safety benefits and the costs of certain and substantial sacrifices in convenience, privacy, aesthetic, and naturalness (Hodgson 1995, Teie and Weatherford 2000, Winter and Fried 2000, Daniel et al. 2003, Collins 2005, Nelson et al. 2005).

In managing for old growth in frequent-fire forests, the relevant issues are complex and often play out across spatial and temporal scales that do not easily fit into normal patterns of human comprehension and concern. People are often reluctant to pay now for benefits that will only be realized much laterperhaps after the current generation is dead. Moreover, forests are dynamic, with conditions at any given location certain to change with time. Finally, people are more likely to attach their values to a specific special place, and often view any change at that place as negative. Although forest managers may appreciate the changing mosaic of forest conditions that occurs in frequent-fire old growth across broad spatial and temporal scales, such a scenario is difficult for most of the public to embrace.

Unfortunately, conventional means of public education and outreach, such as printed brochures and public information messages that feature knowledge change, have not shown an ability to substantially shift public sentiments or behavior toward recommended fire safety actions (Cortner et al. 1990, Cheng and Cortner 2003, Daniel 2003, Nelson et al. 2003, McCaffrey 2004). For the growing segments of the public who favor oldgrowth preservation and naturalness as goals for public forest management (Xu and Bengston 1997, Shields et al. 2002, Nelson et al. 2005), the very concept of old-growth "management" may seem oxymoronic. 
If the public can be convinced that the goal of oldgrowth management is protection and that proposed management policies can effectively achieve that goal, majority support might be achieved. But acceptance will likely be fragile and subject to renegotiation on a case-by-case basis. In that context, managers will need to be clear about both objectives and means, and be as careful in protecting the public's trust as in protecting old-growth forests (Shindler et al. 2002). Public education will be an ongoing challenge, although surveys indicate a significant level of acceptance of some negative side effects in order to reduce the risk of catastrophic fire. For example, in surveys conducted in the Southwest during 2000 and 2003, most respondents expressed acceptance of smoke as a necessary consequence of prescribed fires, at least in concept (Abrams and Lowe 2005).

Although management of old growth in frequentfire forests is fraught with challenges, growing public concern for both forest health and public safety necessitates concerted intervention. As forest managers and policy makers grapple with management issues, they will face critical questions: What is the public willing to sacrifice and tolerate to manage for old growth in frequent-fire forests? How much do we value the ecological integrity of frequent-fire, old-growth forest communities? How much financial burden are we willing to shoulder to restore those values? What risks are we willing to assume? The answers to these questions will determine the extent and success of efforts to reestablish the ecological structure and functions of frequent-fire forests.

Responses to this article can be read online at:

http://www.ecologyandsociety.org/vol12/iss2/art17/responses/

\section{LITERATURE CITED}

Abrams, J. B., and K. Lowe. 2005. Public perceptions of forest restoration in the southwest: a synthesis of selected literature and surveys. Ecological Restoration Institute, Issues in Forest Restoration. Northern Arizona University, Flagstaff, Arizona, USA.

Agee, J. K. 2002. The fallacy of passive management: managing for firesafe forest reserves. Conservation Biology in Practice 3(1):18-25.
Alcoze, T. 2003. First Peoples in the pines: historical ecology of humans and ponderosa. Pages 48-57 in P. Friederici, editor. Ecological restoration of southwestern ponderosa pine forests. Island Press, Washington, D.C., USA.

Anderson, M. K. 2005. Tending the wild: Native American knowledge and the management of California's natural resources. University of California Press, Berkeley, California, USA.

Anderson, M. K., and M. J. Moratto. 1996. Native American land-use practices and ecological impacts. Pages 187-206 in D. C. Erman, editor. Sierra Nevada Ecosystem Project: final report to Congress, volume II, Assessments and scientific basis for management options. University of California, Centers for Water and Wildland Resources, Davis, California, USA.

Arno, S. F. 1980. Forest fire history in the Northern Rockies. Journal of Forestry 78:460-465.

Arno, S. F., and C. E. Fiedler. 2005. Mimicking nature's fire: restoring fire-prone forests in the West. Island Press, Washington, D.C., USA.

Arno, S. F., D. J. Parsons, and R. E. Keane. 2000. Mixed-severity fire regimes in the northern Rocky Mountains: consequences of fire exclusion and options for the future. Pages 225-232 in D. N. Cole, S. F. McCool, W. T. Borrie, and J. O'Loughlin, compilers. Wilderness science in a time of change conference-Volume 5: Wilderness ecosystems, threats, and management. U.S. Forest Service Proceedings RMRS-P-15-VOL-5.

Baker, R. D., R. S. Maxwell, V. H. Treat, and H. C. Dethloff. 1988. Timeless heritage: a history of the Forest Service in the Southwest. U.S. Forest Service Report FS-409. [online] URL: http://www. fs.fed.us/r3/about/history/timeless/index.shtml.

Beardsley, D., C. Bolsinger, and R. Warbington. 1999. Old-growth forests in the Sierra Nevada: by type in 1945 and 1993 and ownership in 1993. U.S. Forest Service Research Paper PNWRP-516.

Beesley, D. 1996. Reconstructing the landscape: an environmental history, 1820-1960. Pages 3-24 in D. C. Erman, editor. Sierra Nevada Ecosystem Project: Final report to Congress, volume II, Assessments and scientific basis for management options. University of California, Centers for Water 
and Wildland Resources, Davis, California, USA.

Berkes, F., J. Colding, and C. Folke. 2000. Rediscovery of traditional ecological knowledge as adaptive management. Ecological Applications 10 (5):1251-1262.

Bonnicksen, T. M.2000. America's ancientforests: from the Ice Age to the Age of Discovery. John Wiley, New York, New York, USA.

Callicott, J. B. 2000. Harmony between men and land: Aldo Leopold and the foundations of ecosystem management. Journal of Forestry 98 (5):4-13.

Carey, A. B. 2003. Restoration of landscape function: reserves or active management? Forestry 76(2):221-230.

Cheng, A. S., and H. J. Cortner. 2003. Policy, political, and institutional dimensions. Pages 51-57 in H. J. Cortner, D. R. Field, and P. Jakes, editors. Humans, fire, and forests: social science applied to forest management. Papers in Restoration Policy, Northern Arizona University Ecological Restoration Institute, Flagstaff, Arizona, USA.

Clary, D. 1986. Timber and the Forest Service. University Press of Kansas, Lawrence, Kansas, USA.

Collins, T. W. 2005. Households, forests, and fire hazard vulnerability in the American West: a case study of a California community. Environmental Hazards 6:23-37.

Cooper, C. F. 1960. Changes in vegetation, structure, and growth of southwestern ponderosa pine forest since white settlement. Ecological Monographs 30:129-164.

Cortner, H. J., P. D. Gardner, and J. G. Taylor. 1990. Fire hazards at the urban-wildland interface: what the public expects. Environmental Management 14:57-62.

Cortner, H. J., M. J. Zwolinski, E. H. Carpenter, and J. G. Taylor. 1984. Public support for firemanagement policies. Journal of Forestry $\mathbf{8 2}$ (6):359-361.

Covington, W. W. 2003. The evolutionary and historical context. Pages 26-47 in P. Friederici, editor. Ecological restoration of southwestern ponderosa pine forests. Island Press, Washington, D.C., USA.

Covington, W. W., and M. M. Moore. 1994. Southwestern ponderosa forest structure: changes since Euro-American settlement. Journal of Forestry 92(1):39-47.

Crumley, C. L. 1994. Historical ecology: a multidimensional ecological orientation. Pages 116 in C. L. Crumley, editor. Historical ecology: cultural knowledge and changing landscapes. School of American Research Press, Sante Fe, New Mexico, USA.

Daniel, T. C. 2003. Social science of wildfire risk management: individual level of analysis. Pages 915 in H. J. Cortner, D. R. Field, and P. Jakes, editors. Humans, fire, and forests: social science applied to forest management. Papers in Restoration Policy, Northern Arizona University Ecological Restoration Institute, Flagstaff, Arizona, USA.

Daniel, T. C., E. Weidemann, and D. Hines. 2003. Assessing public tradeoffs between fire hazard and scenic beauty in the wildland-urban interface. Pages 36-44 in J. L. Jakes, compiler. Homeowners, communities, and wildfire: science findings from the National Fire Plan. U.S. Forest Service General Technical Report NC-231.

Davis, S. 1995. The role of communication and symbolism in interest group competition: the case of the Siskiyou National Forest, 1983-1992. Political Communication 12(1):27-42.

Delcourt, H. R., and P. A. Delcourt. 1997. PreColumbian Native American use of fire on southern Appalachian landscapes. Conservation Biology 11 (4):1010-1014.

Dieterich, J. H. 1980. Chimney Spring forest fire history. U.S. Forest Service Research Paper RM-220.

Erman, D. C. 1999. Sierra Nevada ecosystem project: case study. Pages 305-320 in K. N. Johnson, F. Swanson, M. Herring, and S. Greene, editors. Bioregional assessments: Science at the crossroads of management and policy. Island Press, Washington, D.C., USA.

Fischer, W. C., and A. F. Bradley. 1987. Fire 
ecology of western Montana forest habitat types. U. S. Forest Service, Intermountain Research Station, GTR-INT-223.

Friederici, P. 2003. The "Flagstaff model." Pages 7-25 in P. Friederici, editor. Ecological restoration of southwestern ponderosa pine forests. Island Press, Washington, D.C., USA.

Geores, M. E. 1996. Common ground: the struggle for ownership of the Black Hills National Forest. Rowman and Littlefield Publishers, Inc., Lanham, Maryland, USA.

Gruell, G. E. 1985. Indian fires in the interior West: a widespread influence. Pages 68-74 in J. E. Lotan, editor. Proceedings-Symposium and Workshop on Wilderness Fire. U.S. Forest Service, Intermountain Forest and Range Experiment Station, General Technical Report INT-GTR-182.

Grumbine, R. E. 1994. What is ecosystem management? Conservation Biology 8(1):27-38.

Hessburg, P. F., and J. K. Agee. 2003. An environmental narrative of inland northwest United States forests, 1800-2000. Forest Ecology and Management 178:23-59.

Hirt, P. W. 1994. A conspiracy of optimism: management of the national forests since World War Two. University of Nebraska Press, Lincoln, Nebraska, USA.

Hodgson, R. W. 1995. Strategies for and barriers to public adoption of fire safe behavior. Pages 9398 in D. R. Weise, and R. E. Martin, technical coordinators. The Biswell Symposium: fire issues and solutions in urban interface and wildland ecosystems. U.S. Forest Service General Technical Report SW-GTR-158.

Kay, C. 1995. Aboriginal overkill and native burning implications for modern ecosystem management. Western Journal of Applied Forestry 10:121-126.

Kimmerer, R. W. 2000. Native knowledge for native ecosystems. Journal of Forestry 98(8):4-9.

Kimmerer, R. W., and F. K. Lake. 2001. Maintaining the mosaic: the role of indigenous burning in land management. Journal of Forestry 99:36-41.
Kipfmueller, K. F., and T. W. Swetnam. 2000. Fire-climate interactions in the Selway-Bitterroot Wilderness Area. Pages 270-275 in D. N. Cole, S. F. McCool, W. T. Borrie, and J. O'Loughlin, compilers. Wilderness science in a time of change conference-Volume 5: Wilderness ecosystems, threats, and management. U.S. Forest Service Proceedings RMRS-P-15-VOL-5.

Langston, N. 1995. Forest dreams, forest nightmares: the paradox of old growth in the Inland West. University of Washington Press, Seattle, Washington, USA.

Leopold, A. 1920. "Piute forestry" vs. forest fire prevention. Southwestern Magazine 2:12-13.

1939. A biotic view of land. Journal of Forestry 37:727-730.

1949. A Sand County almanac. Oxford University Press, New York, New York, USA.

Leopold, A. S., S. A. Cain, C. M. Cottam, I. N. Gabrielson, and T. L. Kimball. 1963. Wildlife management in the National Parks. American Forests 69:32-35, 61-63.

Mast, J. N., P. Z. Fulé, M. M. Moore, W. W. Covington, and A. E. M. Waltz. 1999. Restoration of presettlement age structure of an Arizona ponderosa pine forest. Ecological Applications 9 (1):228-239.

McCaffrey, S. 2004. Thinking of wildfire as a natural hazard. Society and Natural Resources $\mathbf{1 7}$ (6):509-516.

McKenzie, M. D., T. H. DeLuca, and A. Sala. 2004. Forest structure and organic horizon analysis along a fire chronosequence in the low elevation forests of western Montana. Forest Ecology and Management 203:331-343.

Merriam, C.H. 1890. Results of a biological survey of the San Francisco Mountain region and desert of the Little Colorado, Arizona. Government Printing Office, Washington, D.C., USA.

Muir, J. 1898. The wild parks and forest reservations of the west. Atlantic Monthly $\mathbf{8 1}$ (483):15-28. 
Nash, R. 1967. Wilderness and the American mind. Yale University Press, New Haven, Connecticut, USA.

Nelson, K. C., M. C. Monroe, and J. FingermanJohnson. 2005. The look of the land: homeowner landscape management and wildfire preparedness in Minnesota and Florida. Society and Natural Resources 18:321-336.

Nelson, K. C., M. C. Monroe, J. F. Johnson, and A. W. Bowers. 2003. Public perceptions of defensible space and landscape values in Minnesota and Florida. Pages 55-62 in P. L. Jakes, compiler. Homeowners, communities, and wildfire: science findings from the National Fire Plan. U.S. Forest Service General Technical Report NC-231.

Nelson, R. H. 1995. The federal land management agencies. Pages 37-59 in R. L. Knight and S. F. Bates, editor. A new century for natural resources management. Island Press, Washington, D.C., USA.

Nie, M.A. 1998. Green sagebrush: the American West, political culture, and environmental politics. Dissertation. Northern Arizona University, Flagstaff, Arizona, USA.

Norse, E. A. 1990. Ancient forests of the Pacific Northwest. Island Press, Washington, D.C., USA.

Oliver, C. D., L. L. Irwin, and W. H. Knapp. 1994. Eastside forest management practices: historical overview, extent of their applications, and their effects on sustainability of ecosystems. U.S. Forest Service General Technical Report PNW-GTR-324.

Pyne, S. J. 1982. Fire in America: a cultural history of wildland and rural fire. Princeton University Press, Princeton, New Jersey, USA.

-2001. Year of the fires: the story of the great fires of 1910. Penguin Books, New York, New York, USA.

Quigley, T. M., R. T. Graham, and R. W. Haynes. 1999. Interior Columbia basin ecosystem management project: case study. Pages 271-287 in K. N. Johnson, F. Swanson, M. Herring, and S. Greene, editors. Bioregional assessments: science at the crossroads of management and policy. Island Press, Washington, D.C., USA.

Regan, C. M. 1997. Old-growth forests in the
Sacramento Mountains, New Mexico: characteristics, stand dynamics and historical distributions. Dissertation, Colorado State University, Fort Collins, Colorado, USA.

Robbins, W. G., and D. W. Wolf. 1994. Landscape and the Intermontane Northwest: an environmental history. U.S. Forest Service General Technical Report PNW-GTR-319.

Savage, M., and J.N. Mast. 2005. How resilient are southwestern ponderosa pine forests after crown fires? Canadian Journal of Forest Resources 35:967-977.

Savage, M., and T. W. Swetnam. 1990. Early $19^{\text {th }}$ century fire decline following sheep pasturing in a Navajo ponderosa pine forest. Ecology 71(6):23742378.

Scurlock, D., and D. M. Finch. 1997. A historical review. Pages 43-67 in W. M. Block and D. M. Finch, technical editors. Songbird ecology in southwestern ponderosa pine forests: A literature review. U.S. Forest Service General Technical Report RM-GTR-292.

Shields, D. J., I. M. Martin, W. E. Martin, and M.A. Haefele. 2002. Survey results of the American public's values, objectives, beliefs, and attitudes regarding forests and grasslands: a technical document supporting the 2000 USDA Forest Service RPA Assessment. U.S. Forest Service General Technical Report RMRS-GTR-95.

Shindler, B., M. Brunson, and G. Stankey. 2002. Social acceptability of forest conditions and management practices: a problem analysis. U.S. Forest Service General Technical Report PNWGTR-537.

Shinneman, D. J., and W. L. Baker. 1997. Nonequilibrium dynamics between catastrophic disturbances and old-growth forests in ponderosa pine landscapes of the Black Hills. Conservation Biology 11(6): 1276-1288.

Stephens, S. L., and L. W. Ruth. 2005. Federal forest-fire policy in the United States. Ecological Applications 15(2):532-542.

Teie, W. C., and B. F. Weatherford. 2000. A report to the Council of Western State Foresters: fire in the West, the wildland/urban interface fire problem. 
Deer Valley Press, Rescue, California, USA.

Turner, N. J., I. J. Davidson-Hunt, and M. O'Flaherty. Living on the edge: ecological and cultural edge as sources of diversity for socialecological resilience. Human Ecology 31(3):439463.

United States Department of Agriculture (USDA) Forest Service. 1996. Status of the Interior Columbia Basin: summary of scientific findings. U. S. Forest Service General Technical Report PNWGTR-385.

USDA and United States Department of Interior (USDI). 1994. Record of decision for amendments to Forest Service and Bureau of Land Management planning documents within the range of the northern spotted owl. U.S. Forest Service Regional Office, Portland, Oregon, USA.

Veblen, T. T., T. Kitzberger, and J. Donnegan. 2000. Climatic and human influences on fire regimes in ponderosa pine forests in the Colorado front range. Ecological Applications 10(4):11781195.

Weaver, H. 1943. Fire as an ecological and silvicultural factor in the ponderosa-pine region of the pacific slope. Journal of Forestry 41:7-15.

1967. Fire and its relationship to ponderosa pine. Proceedings of the Tall Timbers Fire Ecology Conference 7:127-149.

White, G. 2005. The gift of fire. Pages 66-68 in Forestry in Indian Country: models of sustainability for our nation's forests? Evergreen, Winter 20052006, Evergreen Foundation, Portland, Oregon, USA.

Wilkinson, C. 1992. Crossing the next meridian: land, water, and the future of the West. Island Press, Washington, D.C., USA.

Wilkinson, C., and H. M. Anderson. 1987. Land and resource planning in the national forests. Island Press, Washington, D.C., USA.

Williams, A. S. 1908. Logging by steam. Forestry Quarterly 6(1):1-33.

Williams, M. 1989. Americans and their forests: $a$ historical geography. Cambridge University Press,
New York, New York, USA.

Winter, G., and J. S. Fried. 2000. Homeowner perspectives on fire hazard, responsibility, and management strategies at the wildland-urban interface. Society and Natural Resources 13(1):3349.

Xu, Z., and D. N. Bengston. 1997. Trends in national forest values among forestry professionals, environmentalists, and the news MEDIA, 19821993. Society and Natural Resources 10(1):43.

Yaffee, S. L. 1994. The wisdom of the spotted owl: policy lessons for a new century. Island Press, Washington, D.C, USA.

Yazzie, V. 2006. A cultural ethic in tribal forest management and self-determination: the human dimension of silviculture. Dissertation, University of Montana, Missoula, Montana, USA. 